\title{
Speech act in English Interaction Used by Tour Guide in Bali
}

\author{
I Gusti Ayu Vina Widiadnya Putri ${ }^{1}$ and Dewa Ayu Devi Maharani Santika Devi ${ }^{2}$ \\ \{vina.ayu422@gmail.com ${ }^{1}$ and devimaharani17@gmail.com ${ }^{2}$ \} \\ STIBA Saraswati Denpasar-Bali, Indonesia
}

\begin{abstract}
This research analyzed about speech act since there are some tour guides usually escape their main duty when they handling the guest's trip in Bali. We need to analyze about the classes of speech act that used by tour guide in Bali where it is the problem of this research. This research used the speech act theory by John L. Austin (1962). The data of this research have been taken from some of the Balinese Local Tour Guides; they usually handle the guest's trip in Bali and use English frequently. The research method that had been used in collecting data was method of field research. They were collected by recording and interviewing some Balinese local tour guides that used English for the interaction. Based on the result of this research, the Balinese tour guide frequently use three classes of speech act such as locutionary, illocutionary, and perlocutionary act.
\end{abstract}

Keywords: speech act, traveler, guide

\section{Introduction}

This study was conducted to find out about the types of speech acts used by the tour guides in Bali. Language is as a part of human living where nowadays people tend to arise words, for example types of verbal that has something to do with words use physically. To recognize automatic language is to see how a language is spoken by the speakers. The concept of the language distance seems to be related to the process of language identification. The language ideological perception of distinct language practices is, in part, dependent on the social identify of the person using the language and the significance or meaning of it may distinguish largely for different subgroups or the position of subject. The Linguistics factor include the structural sentence, grammatical pattern, and lexicon. Grammatical is the matter of finite concise representation (usually and automaton) of a fixed yet unknown language. The influences of learning two languages are language acquisition and cognitive development, especially the domain of executive functions. Bilinguals frequently switch between their languages in daily life. Language shift is a cause of concern in the communities.

Despite the good development and grammatical structure, each sentence that is spoken will have a significant influence on others. The language that can be produced by speakers will have an impact and affect the partner's speech. J.R Searly mentions that speech act is about performing of some actions while speaking a language, such as making statements, giving commands, asking questions or making promises. Searly also says that communication with all languages conducts speech acts. Therefore, speech acts included in the linguistic 
communication as the basic units. They are not only about language constructions but also concern in the acquaintance of context in which they are performed. This is essential for decoding the whole utterance and its proper meaning. The speech acts are used in common conversation as in jokes or drama. The speech act issues can be analyzed in understanding English language. English language is a foreign language that used by many people to communicate. It can connect different people from various countries to do communication one to another. In travelling, many tourists in different countries use English for the interaction with local people. They need a tour guide to teach them many roles in tourist destination.

The first impression of a tourist when on vacation is the friendliness and attitude of the tour guide who serves him. It means a tour guide have a responsibility in teaching tourists about the culture and sites of his city or town. He may deliver not merely about this knowledge, but also the safety. The responsibility to make the trip interesting, informative and safe is the additional concern of the tour guides. Balinese tour guides have their own roles to explain more culture and customs in Bali. They have to be politer to transfer their knowledge to the tourists, because it is their main duty. Therefore, the speech acts of a tour guide will be considered by the tourist a model of Balinese themselves. The speech acts used by the Balinese tour guides is interesting to be analyzed, since usually they escape their main duty which is being polite and deliver some knowledge to their guests when they have their holiday in Bali. This study analyzed about the classes and implication of the speech act that used by these tour guides.

The data were taken from the Balinese tour guides' utterances while they have some interactions to the guests. They were 10 tour guides in Bali that were recorded and also interviewed in their interactions during the trips. This study used speech act theory from John.L. Austin (1962) as the main theory. Method of research is a procedure needed to do the research better. In this case, method of research covers data source, data collection, and data analysis. The data were collected by using the method of field research.

\section{Result and Discussion}

The discussions were divided into locutionary act, illocutionary act, and perlocutionary act. These three acts are the basic units of formed the speech acts. The locutionary act can be viewed as a mere uttering some words in certain language, while the illocutionary and perlocutionary acts convey a more complicated message for the hearer. An illocutionary act communicates the speaker's intentions behind. The locution and perlocutionary act reveal the effect the speaker wants to exercise over the hearer. This can be demonstrated on a simple example: "would you close the door, please?" The surface form, and also the locutionary act of this utterance is a question with a clear content (close the door). The illocutionary act conveys a request from the part of the speaker and the perlocutionary act emphasizes the speaker's intention: the hearer should go and close the door.

\section{Locutionary act}

There is no other meaning is the characteristic of this component of speech act. It is point out the real utterance and seemingly meaning, including phonetic, phatic, and rhetic acts which dealing with verbal, syntactic and semantic aspects of any meaningful utterance. Commenting on Austin's work, point out that Austin distinguishes three aspects of the locutionary act. Austin claims that to say anything is: (a) always to perform the act of uttering certain noises (a phonetic act), (b) always to perform the act of uttering certain vocab or words ( a phatic act), (c). generally, to perform the act of using that [sentence] or its constituents with 
a certain more or less definite 'sense' and a more or less definite 'reference which together are equivalent to 'meaning' (rhetic act).

\section{Data 1:}

Guide : good afternoon ladies and gentlemen welcome to ngurah rai airport denpasar city.

How is your flight.(Sudiana, Wayan)

Tourist: it's very nice day, I am happy.

This dialogue belongs to locutionary act because the utterance indicates the literal meaning. In that utterance discussed about welcoming guest in the airport. In term of lexical choice, verbs and adjective were mostly appeared. The used of those lexical indicates about the actual utterance and its ostensible meaning. The guide welcoming guest by asking the guest' condition; this utterance has the same sense and same meaning for the speaker and hearer which makes the guest responded by clearly meaningful utterance in saying it's very nice day, I am happy. The meaning from this dialogue is not ambiguous. There is no other meaning in that utterance, this utterance only to great some guest in the airport and ask them by hospitality services.

\section{Data 2:}

Guide : that is good ladies and gentlemen. I am Sudiana from bangli tour and travel. Excuse me. May I know who is the tour leader this group?(Sudiana, Wayan)

Tourist : yes... I'm the tour leader in this group. I'm gommez.

Guide : hello Mr. Gommez glad to meet you.

This dialogue also belongs to Locutionary act because the utterance indicates actual meaning. That dialogue discussed about introduction someone to the other. In this term used the interrogative sentence by marking "who". The used of interrogative sentence in that dialogue indicates the actual utterance by the guide. The utterance was understood by the hearer which means the meaning is delivered well in the expression. The guide asked the guest "who is the tour leader in this group?" then guest response by clearly meaningful utterance in saying yes... I'm the tour leader this group. I'm gommez. The meaning of that utterance is literal. There is no ambiguous meaning in that utterance. This conversation viewed that real introducing their self and asking some questions to make the conversation more enjoyable

\section{Illocutionary}

Illocutionary action is one of the main points of speech acts. As suggested above, illocutionary actions are the speakers performed in producing the given speech. Illocutionary act is the action taken that relates to the intention of the speaker of compilation done. Some of the intentions that the speaker wants to convey to the hearer are, speech as a statement, making requests, giving orders, and giving threats. illocutionary actions can be carried out with communicative utterances which are usually called illocutionary utterances. As Yule (Yule, 1998: 48) claims, the illocutionary act is thus performed via the communicative force of an utterance which is also generally known as illocutionary force of the utterance. illocutionary actions can be carried out with communicative utterances which are usually called illocutionary utterances Basically, the illocutionary act indicates how the whole utterance is to be taken in the conversation. Searle divides the illocutionary speech acts into five categories 
a) Representation is the utterance spoken to express the truth by giving affirmation and conclusions

\section{Data 3:}

Guide :all right ladies andgentleman. Bali is one island which is famous in the world. Bali famous with name "pulau seribu pura" (one thousand of temples) world heaven and etc. Bali has eight regencies and the capital of Bali is Denpasar. Denpasar is the central of economy and government in Bali. (Adi Surya, Ketut)

In this utterance, the guide informs the hearer about Bali Island in general. The utterance 'Bali famous with name pulau seribu pura (one thousand island)' has an intention to state an opinion. The designation for Bali with 'one thousand of temples' has been familiar with the tourists who have visited Bali. Therefore, this information is considered asserting one of the truths to expressed Bali. That utterance is spoken to express the truth by giving the guest affirmative and conclusion about Bali island in general.

b) Directives are An order to get something from the speaker by giving orders to the speaking partner

\section{Data 4:}

Guide : Could you arrange my group baggage's, there are 6 baggages.(Sudiana, Wayan)

Data 5:

Guide :well ladies and gentlemen. May I take you baggage tag? (Sudiana, Wayan)

Data 6:

Guide : Ladies and gentlemen. Could you wait me here I will take your baggages? (Parwata,

Ketut)

Data 7:

Guide : Please hold your hand luggage carefully. Be careful with you head and your steps (Adi Surya, Ketut)

Data 8:

Guide : Ladies and gentleman. Here you boarding pass. Please follow me to boarding gate II (Mandra, Nyoman)

Data 9:

Guide : well ladies and gentleman. Please take a seat then wait your boarding pass here. (Parwata, Ketut)

In data $6,7,8,9$, speakers used imperative sentence to express the utterances. But in data 4 and 5 the speakers express the utterances by using interrogative sentences. Those data above can be categorized as Illocutionary acts for directives because the speaker needed for requesting or ordering someone to do something. The utterances are considered as polite requests since they used the words please, could you, may $I$.

c) Commit is the utterance intended to give promises and offers to the speaking partner Data 10:

Guide : well ladies and gentleman I will meet you tonight for welcome dinner party at 06.30 PM. I hope you have a nice rest.(Mandra, Nyoman) 
In data 10, the speaker tried to give promising to someone in saying 'I will meet you tonight'. Since the utterance indicates the speaker wanted to do something in some future, therefore it is concluded as illocutionary acts for commissive.

d) Expressives express a psychological state (e.g. thanking, congratulating)

\section{Data 11:}

Guide : all right, I would like to say thank you very much to have our travel in your trip. On behalf of my travel I do apologize for your inconvenient and have a nice flight go home. (Sudiana, Wayan)

In data 11 , the speaker expressed his psychological feeling by saying 'thank you very much and our apology for your inconvenient' to the other. These utterances belong to illocutionary acts for expressive because of the psychological state. The speaker said their felling to asking apologize and thank you to the guest.

e) The declaration is the direct integration of different contents in linguistic sentences to declare something to the partner

\section{Data 12:}

Guide: After here, I give you some souvenirs that you can bring to your country (Parwata, Ketut)

In data 12, the speaker has a specific intention to give souvenirs for the guests. It used declaration way in delivering the intention. This utterance belongs to illocutionary acts of declarations meaning.

\section{Perlocutionary Acts}

Perlocutionary act is the point of three types of speech acts. Perlocutionary aims to produce effects from listeners. Perlocutionary actions affect the listener's speech given by the speaker. the utterance can influence listeners from various things

\section{Data 13:}

Guide: This shop is one of the best shopping places in Gianyar. Where you can find all the art work of Balinese artists. I think you should go to this place.(Sudiana, Wayan)

Guest: Yeah, why not. I'll love to visit the shop then. Let's go

In the data above, the speaker wanted to promote a shop to the guest. He made a statement which try to persuade the guest to visit the shop instead of other shop. His utterance can be concluded as perlocutionary acts because the utterance produces an effect to the guest as the hearer. The effect is the guest decided to visit the shop mentioned. It means the response of the guest elicited by persuading of the speaker. To state that Illocutionary acts are successful, if the hearer can interest to visit the shop. However as perlocutionary act it succeed only if the hearer receive the effect from the speaker. In the utterance the effect obtained from the 
utterance is that the guest is directly interested and wants to visit the store after the utterance has been made.

\section{Conclusion}

Tour Guide in Bali frequently use three classes of speech act such as locutionary, illocutionary, and perlocutionary act. The illocutionary act classes that found in those data those are the intentions that the speaker wants to convey to the hearer are, speech as a statement, making requests, giving orders, and giving threats. The mostly speech act categorize that used by the Balinese tour Guide is Directives speech act because the main duty of a guide is to give instruction and guided the guest while they are traveling in Bali, therefore this kind of speech act is very useful to use in their conversation. The other two kinds of speech act are helping the guides in constructing conversation to deliver their intentions to the guests.

\section{Acknowledgement.}

We show the gratitude to God, the informants who have helped in this study and also for the editorial boards and publishing team of EAI Publisher for their contribution to the process of publishing this paper.

\section{References}

[1] Cowley, S, J and Markos, A: Evolution, lineages and human language. Lang sci. pp. 1-11 (2018)

[2] Irtza, S, Sethu, V Ambikairajah, E, and Li, H : Using Language cluster models in hierarchical language identification. Speech Commun. Vol 100, pp. 30 -40 (2018)

[3] Gamallo, P, Pichel, J.R and Alegria, I : From language identification to language distance, Phys. A Stat. Mech. Its Appl. Vol 484, pp. 152-162 (2017)

[4] Henderson, K, 1 : Teacher language ideologies mediating classroom -level language policy in the implementation of dual language bilingual education. Linguist. Educt. Vol 42, pp $21-33$ (2017)

[5] Gobbo, F : Are planned languages less complex than natural language? Lang Sci. vol.60, pp. 36-52 (2017)

[6] Fisman, D : Infering regular languages and co-languages, J. Log. Algebr. Methods Program vol. 98, pp 27-49 (2018)

[7] Goriot, C, Broersma, M, McQueen, J.M, Unsworth, S and Van Hout, R: Language balance and switching ability in children acquiring English as a second language. J. Exp Child Psychol. Vol 173. Pp. 168-186 (2018)

[8] De Bruin A, Samuel, A, G and Dunabeita, J, A: Voluntary language switching: when and why do bilinguals switch between their languages? J. Mem Lang. vol 103. Pp 28-43 (2018)

[9] Hauck, J.D: the origin of language among the Ache, Lang. vol 103.pp 28-43 (2018)

[10] High C. Bodies that speak: Languages of differentiation and becoming Amazonia/. Lang Commun, pp 1-11 (2018)

[11] Hozl, R, Jain, S and Stephan, F: Learning pattern languages over groups. Theor comput. Sci. vol. 742. Pp. 66-81 (2018)

[12] Maason-Apps, E, Stojanovik.V. Houston-Price, C and Buckley, S: Longitudinal Predictors of early language in infants with Down syndrome. A preliminary study. Res. Dev. Disabil pp. 0-1 
[13] Li, C, Jiang. G and Dewaele, J, M, Understanding Chinese high school students' foreign language enjoyment: Validation of the Chinese version of the Foreign Language Enjoyment scale System. Vol 76, pp, 183-196 (2018)

[14] Austin, John Langshaw. 1962. How to do things with words. Press London: Oxford : University

[15]Bach Kent, Robert M. Harnish. 1979. Linguistic communication and Speech Acts. Cambridge: The MIT Press.

[16] Leech, Geoffrey.1983.Principles of Pragmatics. New York: Longman Singapore Publishing.

[17] Searle, John R. 1976. Speech Acts. London: Syndics of the Cambridge University Press.

[18] Searle, John R. 1979. Expression and meaning. Cambridge: Cambridge University Press,

[19] Yule, George. 1998. Pragmatics. Oxford: Oxford University Press. 